\title{
ANALISIS GAYA KEPEMIMPINAN KEPALA MADRASAH TSANAWIYAH AL-HUDA DESA MOJODUWUR KECAMATAN NGETOS KABUPATEN NGANJUK
}

\author{
Nur Isna Indah Kurniawati \\ SDN 52 Nganjuk \\ nurisnaindahkurniawati@gmail.com
}

\begin{abstract}
Abstrak.
Kepala Madrasah merupakan pemimpin professional di lembaga pendidikan yang mempunyai peran sangat penting dan sangat strategis dalam mewujudkan suatu tujuan, mengingat posisinya yang secara struktural sebagai pimpinan legal formal memiliki kekuasaan penuh pada lembaga yang dipimpinnya. Kepala madrasah merupakan pimpinan tertinggi dalam lembaga pendidikan . Gaya kepemimpinan kepala madrasah sangatlah mempengaruhi terwujudnya madrasah yang memenghasilkan manusia - manusia yang bertakwa, berbudi pekerti luhur, dan manusia yang menguasai teknologi informasi. Atas dasar itu, penelitian ini difokuskan pada gaya Kepemimpinan kepala madrasah tsanawiyah Al-Huda Mojoduwur Ngetos Nganjuk. Penelitian ini bertujuan (1) Mendeskripsikan Gaya Kepemimpinan Kepala Madrasah Tsanawiyah Al-Huda Desa Mojoduwur Kecamatan Ngetos Kabupaten Nganjuk. (2) Mendeskripsikan Strategi yang Digunakan Kepala Madrasah dalam Pelaksanaan Gaya kepemimpinan Kepala Madrasah Tsanawiyah Al-Huda Desa Mojoduwur Kecamatan Ngetos Kabupaten Nganjuk.(3) Mendeskripsikan Interaksi Sosial kepala Madrasah dengan Seluruh Warga Madrasah Tsanawiyah Al-Huda Desa Mojoduwur Kecamatan Ngetos Kabupaten Nganjuk.

Hasil penelitian menunjukkan bahwa : (1) Gaya kepemimpinan yang diterapkan oleh kepala madrasah tsanawiyah Al-Huda adalah Demokrasi. (2) Strategi yang Digunakan Kepala Madrasah dalam Pelaksanaan Gaya kepemimpinan Kepala Madrasah Tsanawiyah Al-Huda Desa Mojoduwur Kecamatan Ngetos Kabupaten Nganjuk yaitu niat (perencanaan), kemitraan (andil), dan evaluasi. (3) Kepala madrasah menjalin interaksi sosial secara horizontal dengan guru dan karyawan madrasah tsanawiyah Al-Huda Ngetos Nganjuk dan menjalin interaksi sosial secara vertikal dengan siswa siswi madrasah tsanawiyah Al-Huda Ngetos Nganjuk
\end{abstract}

\section{Kata Kunci : Manajemen Pembelajaran, Aqidah Akhlak, Multikultural}

\section{Pendahuluan}

Peran kepemimpinan dalam pendidikan di Indonesia Kurang mendapat perhatian. Sebab kepemimpinan bukan merupakan salah satu masalah utama managemen sekolah yang diteliti di Indonesia. Bahkan, tidak terdapat persyaratan formal kepemimpinan bagi orang-orang yang berminat menjadi kepala sekolah. Jalal dan Supriadi dalam Raihani menemukan bahwa kebanyakan kepala sekolah di Indonesia tidak memperoleh pendidikan yang layak untuk peran mereka sebagai kepala sekolah, dan beberapa kepala sekolah dasar hanya lulusan sekolah menengah, khususnya di daerah pedesaan. ${ }^{1}$

Seharusnya kepemimpinan harus lebih diperhatikan sebab memegang peranan penting dalam kemajuan lembaga. Demikian pula adanya praktik-praktik terkini tentang kepemimpinan dalam organisasi menunjukkan betapa pentingnya kepemimpinan. Perhatian ini sejalan dengan era yang ditandai dengan perubahan-perubahan dramatis dalam berbagai bidang kehidupan . di era

1 Raihani (2010), Kepemimpinan Sekolah Transformatif, LkiS, Yogyakarta, hlm. 4 
perubahan ini, kepemimpinan sangat penting dalam memadu peningkatan prestasi dan pengembangan sekolah. Dalam banyak penelitian yang telah dilakukan oleh para peneliti terdahulu, kepemimpinan kepala sekolah menjadi faktor utama terhadap keberhasilan sekolah. Demikian pula kesadaran akan pentingnya kepemimpinan sebagai kunci keberhasilan sekolah. ${ }^{2}$

Namun Indonesia akhir-akhir ini sedang dilanda krisis multidimensional sehingga sulit menemukan sosok pemimpin idealis yang memiliki komitmen tinggi. Oleh karena itu, madrasahmadrasah hendaknya berupaya mencetak sosok pemimpin yang bekualitas dan professional sesuai kepemimpinan yang dicontohkan Nabi Muhammad dan para pemimpin masa lalu.

Pedoman kepemimpinan dari Rasulullah yang sering kita dengar siddiq, amanah, fathonah dan balaghoh betul-betul dicontohkan oleh beliau. ${ }^{3}$ Beliau adalah seorang yang pemberani , tegas, mempunyai pengendalian diri, rasa percaya diri yang luar biasa, penyabar dan tabah. Rasulullah punya komitmen kuat terhadap keadilan dan persamaaan atau kesetaraan. ${ }^{4}$ Beliau sangat dermawan yang sama sekali tidak punya minat terhadap harta benda.

Rasulullah mempunyai visi, misi dan tujuan yang kuat. Visi kebesaran Nabi Muhammad SAW sebagai seorang rosul telah melopori paradigma Tauhidiyah (keesaan Tuhan) dan menuju ketakwaan dengan kekuatan iman. ${ }^{5}$

Misinya adalah memperjuangkan agama Allah SWT melalui pengorbanan dan jihad, serta berperang melawan kebodohan dengan menyebarkan pesan melalui ketaqwaan dan amal sholeh. Tujuan,

2 Nurul Hidayah (2016), Kepemimpinan Visioner Kepala Sekolah Dalam Meningkatkan Mutu Pendidikan, Ar-Ruzz Media, Yogyakarta, Hlm. 29

3 Salahuddin Wahid (2011), Berguru Pada Realitas, UIN Maliki Press, Malang, hlm. 366

4 Ibid., hlm. 367

5 Ismail Noor (2011) Manajemen Kepemimpinan Muhammad SAW: Mencontoh Teladan Kepemimpinan Rasul untuk Kesempurnaan Manajemen Modern, Mizan, Bandung, hlm. 19 sasaran dan target rasullullah SAW yang telah dicapai dalam menyampaikan risalah islam adalah seluruh umat rasulullah SAW berada dijalan Allah SWT, bertaqwa dan menjadi hamba Allah SWT yang sholeh sehingga bahagia didunia dan diakherat. Dalam perjuangannya kendati terus menerus mendapat pelecehan, siksaan dan hinaan dari mayoritas kepala suku kaum quraisy, Nabi Muhammad SAW tetap tegak dijalan Allah SWT. ${ }^{6}$

Pemimpin masa lalu, tumbuh dari bawah tidak tergantung pada pemimpin lainnya. Mereka punya karakter, punya sikap, punya prinsip, punya loyalitas dan tidak banyak yang oportunis atau penjilat. ${ }^{7}$ pemimpin masa lalu hidup sederhana, terus terang, setia, kritis, penuh tanggung jawab dan tidak memanfaatkan jabatan. Pak Agus Salim menyatakan bahwa memimpin adalah menderita. Umumnya pemimpin masa lalu adalah negarawan menurut The World Book Encyclopedia, " $a$ statesmen is a person with a broad knowledge of government and politics, who take a leading part in public affairs. Most people think of statesmen being concerned with the needs and interest of their country as a whole. In contrast, they think of politicians as having only party or political aims. Salah satu ucapan dari Winston Churcill yang terkenal ialah : The duty my part ends when the duty to my country begins. ${ }^{8}$ Pemimpin masa lalu umumnya punya integritas, yaitu karakter, etika dan moral. Pemimpin yang punya integritas harus memenuhi beberapa syarat yaitu pertama, harus transparan. Kedua, harus bisa dipercaya dengan menepati janjinya. Ketiga, harus berani bertanggung jawab atas segala keputusan. Keempat, harus bersikap konsisten. Contoh kepemimpinan mereka sangat berbeda dengan zaman sekarang yang hanya mementingkan diri sendiri. Pemimpin yang hanya berharap mendapatkan kehormatan, fasilitas, dan

6 Nurul Hidayah (2016), Kepemimpinan Visioner Kepala Sekolah Dalam Meningkatkan Mutu Pendidikan, Ar-Ruzz Media , Yogyakarta, hlm. 96

7 Salahuddin Wahid (2011), Berguru Pada Realitas, UIN Maliki Press, Malang, halm 361

8 Ibid., hlm. 362 
apalagi prestise, maka tidak akan mendapatkan apa-apa dari kepemimpinannya itu. ${ }^{9}$ Pemimpin yang seperti itu hanya akan menimbulkan 1001 kasus seperti korupsi, banyak anak terlantar, busung lapar dan lain-lain.

Oleh karena itu kepala madrasah sebagai seorang pemimpin harus mencontoh apa yang telah dicontohkan Nabi Muhammad SAW dan pemimpin masa lalu, harus memiliki obsesi yang kuat terhadap pembelajaran dengan kemampuan menejerial yang profesional, dengan mengintegrasikan secara tepat seluruh karakteristik dan model tujuan, kurikulum, pembelajaran, evaluasi, standar, dan iklim kelas. Kepala madrasah melakukan monitoring dan pengawasan melekat dengan hati-hati dan membantu guru dalam melaksanakan pembelajaran.

Untuk menanamkan peranannya ini kepala sekolah harus menunjukkan sikap persuasive dan keteladanan. Sikap persuasif dan keteladanan inilah yang akan mewarnai kepemimpinan termasuk didalamnya pembinaan yang dilakukan oleh kepala sekolah terhadap guru yang ada disekolah tersebut. Kepala sekolah sebagai educator, supervisor, motivator, yang harus melaksanakan pembinaan kepada para karyawan, dan para guru disekolah yang dipimpinnya karena faktor manusia merupakan faktor sentral yang menentukan seluruh gerak aktivitas suatu organisasi, walau secanggih apapun teknologi yang digunakan tetap faktor manusia yang menentukannya.

Dalam fungsinya sebagai penggerak para guru, kepala sekolah harus mampu menggerakkan guru agar kinerjanya menjadi meningkat karena guru merupakan ujung tombak untuk mewujudkan manusia yang berkualitas. Guru akan bekerja secara maksimum apabila didukung oleh beberapa faktor diantaranya adalah kepemimpinan kepala sekolah.

Dengan demikian bagi kepala sekolah dalam memotivasi guru hendaknya

9 Imam Suprayogo (2011), Refleksi Pemikiran Menuju Indonesia Baru, UIN Maliki Press, Malang, hlm. 125 menyediakan peralatan, membuat susasana kerja yang menyenangkan, dan memberi imbalan yang layak baik segi moneter maupun non moneter. Disamping guru sendiri harus mempunyai daya dorong yang berasal dari dalam dirinya untuk berprestasi dalam karirnya sebagai pendidik, pengajar dan pelatih tujuan sekolah ( tujuan pendidikan ) dapat tercapai.

Kepala sekolah sebagai pemimpin sekolah mempunyai tugas yang sangat berat dalam rangka meningkatkan kualitas sekolah. Guru sebagai salah satu komponen yang terpenting dalam pendidikan, terutama dalam hal mengatasi berbagai permasalahan yang berkaitan dengan peningkatan mutu pendidikan, dituntut untuk bisa menjadi guru professional. Dengan keadaan perkembangan masyarakat, maka mendidik merupakan tugas berat dan memerlukan seseorang yang cukup memiliki kemampuan yang sesuai dengan jabatan tersebut, sebab mendidik adalah pekerjaan professional yang tidak dapat diserahkan kepada sembarang orang. ${ }^{10}$

Mutu guru tidak akan ada atau berjalan mulus tanpa adanya usaha-usaha yang dilakukan oleh kepala sekolah, sebab salah satu diantara cara guru agar bisa menjadi guru professional adalah dengan adanya upaya-upaya yang dilakukan oleh kepala sekolah dalam rangka meningkatkan mutu guru. Hal ini sangat cocok sekali, karena kepala sekolah adalah orang yang akan menjadikan sekolah itu maju, disamping dia juga harus memperhatikan hal ihwal guru terutama dalam hal profesionalisme guru tersebut. ${ }^{11}$

MTs Al- Huda Ngetos Nganjuk merupakan madrasah swasta dibawah naungan kementerian Agama, yang saat ini mulai berusaha berkembang baik. Tatanan madrasah akan terjamin apabila gaya kepemimpinan kepala madrasah tepat dan berjalan sesuai norma. Kepala MTs Al-

10 Mulyasa (2011), Menjadi Guru Profesional Menciptakan Pembelajaran Kreatif dan Menyenangkan, PT Remaja Rosdakarya Offest, Bandung, hlm. 26

11 Ibid., 23 
Huda Ngetos saat ini berupaya meningkatkan kualitas madrasah dengan berbagai cara misalnya dengan menerapkan kedisiplinan seluruh warga madrasah dengan sungguh sungguh, menerapkan dengan baik budaya religius, memperhatikan kesejahteraan guru dan menata keuangan madrasah dengan baik. Kualitas madrasah sudah mulai terbentuk, akan tetapi butuh peningkatan yang lebih baik lagi, karena madrasah memiliki peran yang sangat penting dalam menghasilkan output yang sangat berkualitas yaitu generasi yang memiliki pengetahuan luas dan berpegang teguh pada agama.

Berdasarkan paparan di atas, penulis tertarik untuk meneliti masalah tersebut dengan judul Analisis Gaya Kepemimpinan Kepala Madrasah Tsanawiyah Al-Huda Desa Mojoduwur Kecamatan Ngetos Kabupaten Nganjuk Tahun 2017.

Berdasarkan konteks penelitian di atas maka penulis merumuskan fokus penelitian sebagai berikut: pertama, Gaya kepemimpinan Kepala Madrasah Tsanawiyah Al-Huda Desa Mojoduwur Kecamatan Ngetos Kabupaten Nganjuk. Kedua, Strategi yang Digunakan Kepala Madrasah dalam Pelaksanaan Gaya kepemimpinan Kepala Madrasah Tsanawiyah Al-Huda Desa Mojoduwur Kecamatan Ngetos Kabupaten Nganjuk. Dan ketiga, Interaksi Sosial kepala Madrasah dengan Seluruh Warga Madrasah Tsanawiyah Al-Huda Desa Mojoduwur Kecamatan Ngetos Kabupaten Nganjuk.

\section{Kajian Pustaka \\ Tinjauan Kepemimpinan}

Kepemimpinan dalam islam disebut "imamah". Imamah dari kata "imam" yang artinya "pemimpin" atau" ketua"dalam suatu organisasi atau lembaga. ${ }^{12}$ Pemimpin berperilaku untuk membantu organisasi dengan kemampuan

12Aminuddin dkk (2010), Pendidikan Agam Islam Untuk Perguruan Tinggi Umum, Ghalia Indonesia, Bogor, hlm. 209 maksimal dalam mencapai tujuan. ${ }^{13}$ Pemimpin tidak berdiri sendiri disamping, melainkan mereka memberikan dorongan dan memacu (to prod), berdiri di depan yang memberikan kemudahan untuk kemajuan serta memberikan inspirasi organisasi dalam mencapai tujuan. Kepemimpinan merupakan proses ketika seseorang berupaya memengaruhi sekelompok orang untuk mencapai kesuksesan atau tujuan bersama. ${ }^{14}$

Secara sederhana kepemimpinan diartikan sebagai pelaksanaan otoritas dan pembuatan keputusan, pengertian tersebut menunjukkan bagaimana seorang pemimpin mampu menggunakan kewenangan untuk menggerakkan organisasi melalui keputusan yang dibuat. Sedangkan menurut istilah kepemimpinan adalah proses mempengaruhi aktivitas individu atau group untuk mencapai tujuan-tujuan tertentu dalam situasi yang telah ditetapkan. Dalam mempengaruhi aktifitasnya individu pemimpin menggunakan kekuasaan, kewenangan, pengaruh, sifat dan karakteristik, dan Tujuannya adalah meningkatkan produktivitas dan moral kelompok. ${ }^{15}$

Dalam Islam istilah kepemimpinan sering diidentikkan dengan istilah khilafah dan orangnya di sebut kholifah dan Ulil Amri yang orangnya disebut Amir (pemegang kekuasaan). ${ }^{16}$

Kepemimpinan juga dapat diartikan sebuah istilah yang digunakan untuk menggambarkan suatu kegiatan untuk mempengaruhi orang agar melakukan sesuatu dalam mencapai tujuan bersama. ${ }^{17}$ Pengertian yang lebih populer menunjukkan pada pola keharmonisan interaksi antara pemimpin dengan

\footnotetext{
13Wahjosumidjo (2010),Kepemimpinan Kepala MadrasahTinjauan Teoritik dan Permasalahannya, PT Raja Grafindo Parsada, Jakarta, hlm. 104

${ }^{14}$ Arini Tathagati (2016), Orang Kreatif Memimpin Dunia, Progressio Jakarta, Hlm. 35

15 Imam Suprayogo, (2011), Revormulasi Visi

Pendidikan Islam, Malang: Stain Press, cet. I, Hal. 161

16 Ibid,...hal 162

17 Imam Suprayogo (2011), Refleksi

Pemikiran Menuju Indonesia Baru, UIN Maliki Press, Malang, hlm. 139
} 
bawahan sehingga kewenangan yang dimiliki oleh seorang pemimpin diimplementasikan dalam bentuk bimbingan dan pengarahan terhadap bawahan. Pola interaksi biasanya diawali dengan upaya mempengaruhi bawahan agar mereka mau digerakkan sesuai dengan tujuan organisasi.

Kepemimpinan juga diterjemahkan ke dalam istilah: sifat-sifat prilaku pribadi, pengaruh terhadap orang lain, pola-pola interaksi, hubungan kerja sama antar kedudukan dari suatu jabatan administrasi. ${ }^{18}$

Kepemimpinan merupakan kemampuan dan keterampilan seseorang yang menduduki jabatan sebagai pemimpin suatu kerja untuk mempengaruhi prilaku orang lain terutama bawahanya untuk berfikir dan bertindak sedemikian rupa sehingga melalui prilaku yang positif ia memberikan sumbangsih nyata dalam pencapaian tujuan organisasi. ${ }^{19}$

Menurut Gary Yukl dalam terbitan bukunya, dalam Mulyadi menyatakan bahwa memahami kepemimpinan sebagai sebuah proses mempengaruhi dalam suatu kelompok untuk mencapai tujuan orang secara bersama. ${ }^{20} \mathrm{Hal}$ ini dapat dipahami dari penjelasan sebagai berikut: Kepemimpinan didefinisikan secara luas sebagai proses proses yang memengaruhi interpretasi mengenai peristiwa-peristiwa para pengikut, pilihan dari sasaran-sasaran bagi kelompok atau orang, pengorganisasian dari aktivitas-aktivitas tersebut untuk mencari sasaran, pemeliharaan hubungan, kerjasama dan teamwork, serta perolehan dukungan dan kerjasama dari orang orang yang ada diluar kelompok atau orang.

Secara definisi, kepemimpinan memiliki berbagai perbedaan pada

18 Wahjosumidjo, 2012, Kepemimpinan Kepala Sekolah tinjauan teoritik dan permasalahan, Jakarts: PT. Raja Grafindo Persada, Hal. 17

19 Moch Idochi Anwar (2014), Administrasi Pendidikan Dan Manajemen Biaya Pendidikan, Alfabeta, Bandung, hlm. 77

20Mulyadi (2010), Kepemimpinan Kepala Madrasahdalam Mengembangkan Budaya Mutu, UIN Maliki Press , Malang, hlm. 1 berbagai hal, namun demikian yang pasti ada pada definisi kepemimpinan adalah adanya suatu proses dalam kepemimpinan untuk memberikan pengaruh sosial pada orang lain, sehingga orang lain tersebut menjalankan suatu proses sebagaimana yang diinginkan oleh pemimpin, sebagaimana dinyatakan oleh Muhaimin. ${ }^{21}$

Secara singkat dapat dijabarkan bahwa unsur-unsur kepemimpinan dalam sebuah organisasi adalah sebagai berikut: a. orang-orang sebagai motor atau daya penggerak di satu pihak, b. orang-orang sebagai sumber di lain pihak.

Kepemimpinan adalah Usaha yang dilakukan oleh seseorang dengan segenap kemampuan yang dimilikinya untuk : mempengaruhi, mendorong, mengarahkan dan menggerakkan orang-orang yang dipimpin supaya mereka mau bekerja dengan penuh semangat dan kepercayaan dalam mencapai tujuan-tujuan organisasi. ${ }^{22}$

Dari definisi di atas dapat disimpulkan bahwa kepemimpinan adalah kelebihan kesanggupan berupa kualitas kerja dari seorang pemimpin untuk mempengaruhi orang-orang agar mau melakukan kegiatan-kegiatan dan bersama-sama mencapai tujuan yang telah ditetapkan dan dengan didukung oleh semua fasilitas yang ada, sehingga pekerjaan berjalan lancar dan tujuan tercapai secara efektif dan efisien.

\section{Gaya Kepemimpinan}

Gaya artinya sikap, gerak, tingkah laku, sikap yang elok, gerak-gerik yang bagus, kekuatan, kesanggupan, untuk berbuat baik. ${ }^{23}$ Gaya kepemimpinan adalah cara yang digunakan pemimpin dalam mempengaruhi pengikutnya. ${ }^{24}$

21Muhaimin (2010), et.al, Manajemen dan Kepemimpinan Sekolah/Madrasah, Kencana Prenada Media Group, Jakarta, hlm. 29

22 Burhanuddin, 2011, Analisis Administrasi Manajemen dan Kepemimpinan Pendidikan, Bumi Aksara, Malang, halm. 63.

23 Qonita Alya (2011), Kamus Bahasa Indonesia untuk Pendidikan Dasar, Indah Jaya Adipratama,Bandung, hlm. 226

24 E. Mulyasa (2011), Menjadi Kepala Sekolah Profesional, Remaja Rosdakarya, bandung, hlm.108 
Dalam hal ini pengertian gaya kepemimpinan bisa bermacam-macam, akan tetapi pada dasarnya masih mempunyai benang merah yang sama: (1) Gaya Kepemimpinan adalah sikap, gerakgerik atau lagak yang dipilih oleh seorang pemimpin dalam menjalankan tugasnya. (2) Gaya Kepemimpinan adalah suatu pola perilaku yang konsisten yang ditunjukkan pemimpin dan diketahui pihak lain ketika pemimpin berusaha mempengaruhi kegiatan-kegiatan orang lain. (3) Gaya Kepemimpinan adalah pola perilaku dan strategi yang disukai dan sering diterapkan oleh seorang pemimpin. Gaya kepemimpinan yang dimaksud adalah teori kepemimpinan dari pendekatan perilaku pemimpin. Dari satu segi pendekatan ini masih difokuskan lagi pada gaya kepemimpinan (leadership style), sebab gaya kepemimpinan bagian dari pendekatan perilaku pemimpin yang memusatkan perhatian pada proses dinamika kepemimpinan dalam usaha mempengaruhi aktivitas individu untuk mencapai suatu tujuan dalam suatu situasi tertentu.

Gaya kepemimpinan ialah polapola perilaku pemimpin yang digunakan untuk mempengaruhi aktuivitas orangorang yang dipimpin untuk mencapai tujuan dalam suatu situasi organisasinya dapat berubah bagaimana pemimpin mengembangkan program organisasinya, menegakkan disiplin yang sejalan dengan tata tertib yang telah dibuat, memperhatikan bawahannya dengan meningkatkan kesejahteraanya serta bagaimana pimpinan berkomunikasi dengan bawahannya.

Gaya kepemimpinan merupakan pola perilaku seorang pemimpin yang khas pada saat mempengaruhi anak buahnya, apa yang dipilih oleh pemimpin untuk dikerjakan, cara seorang pemimpin bertindak dalam proses mempengaruhi para anggota kelompok membentuk gaya kepemimpinannya. ${ }^{25}$ Pemaksaan kehendak oleh atasan mestinya tidak dilakukan.

25 E. Mulyasa (2013), Manajemen Berbasis Sekolah, Konsep Strategi dan Implementasinya, Remaja Rosdakarya, bandung, hlm. 108
Namun pemimpin dalam menerapkan gaya kepemimpinan yang tepat merupakan tindakan yang bijaksana kepada bawahan, maka akan terjadi kegagalan dalam pencapaian tujuan organisasi. Selanjutnya gaya kepemimpinan digunakan dalam berinteraksi dengan bawahannya, melalui berinteraksi ini antara atasan dan bawahan masing-masing memilki status yang berbeda. Berinteraksinya dua status yang berbeda terjadi, apabila status pemimpin dapat mengerti keadaan bawahannya. Pada umumnya bawahan merasa dilindungi oleh pimpinan apabila pimpinan dapat menyejukkan hati bawahan terhadap tugas dibebankan kepadanya. Cara berinteraksi oleh pimpinan akan mempengaruhi tujuan organisasi. Bawahan umumnya lebih senang menerima atasan yang mengayomi bawahan sehingga perasaa senang akan tugas timbul, yang pada akhirnya meningkatkan kinerja karyawan.

Pemimpin yang bijaksana umumnya lebih memperhatikan kondisi bawahan guna pencapaian tujuan organisasi. Gaya yang akan digunakan mendapat sambutan hangat oleh bawahan sehingga proses mempengaruhi bawahan berjalan dengan baik dan disatu sisi timbul kesadaran untuk bekerja sama dan bekerja produktif. Bermacam-macam cara mempengaruhi bawahan tersebut guna kepentingan pemimpin yaitu tujuan organisasi. Pimpinan dalam pencapaian tujuan yang telah ditetapkan pada tugas dan fungsi, melalui proses komunikasi dengan bawahannya sebagai dimensi dalam kepemimpinan dan teknik-teknik untuk memaksimalkan pengambilan keputusan.

Gaya kepemimpinan adalah suatu cara yang digunakan pemimpin dalam berinteraksi dengan bawahanya. ${ }^{26}$ Pola dasar terhadap gaya kepemimpinan yang lebih mementingkan pelaksanaan tugas oleh para bawahannya, menuntut penyelesaian tugas yang dibebankan padanya sesuai dengan keinginan

26 Fandy Tjiptono \& Anastasia Diana (2011), Total Quality Management, Andi, Yogyakarta, hlm. 161 
pimpinan. Pemimpin menuntut setiap anggota seperti dirinya, menaruh perhatian yang besar dan keinginan yang kuat dalam melaksanakn tugas-tugasnya. Pemimpin beranggapan bahwa bila setiap anggota melaksanakan tugasnya secara efektif dan efisien, pasti akan dicapai hasil yang diharapkan sebagai penggabungan hasil yang dicapai masing-masing anggota.

Gaya kepemimpinan yang berpola untuk mementingkan pelaksanaan kerjasama, pemimpin berkeyakinan bahwa dengan kerjasama yang intensif, efektif, dan efisien, semua tugas dapat dilaksanakan secara optimal. Pelaksanakan dan bagaimana tugas dilaksanakan berada diluar perhatian pemimpin, karena yang penting adalah hasilnya bukan prosesnya. Namun jika hasilnya tidak seperti yang diharapkan, tidak ada pilihan lain, selain mengganti pelaksananya tanpa menghiraukan siapa orangnya. Pola dasar ini menggambarkan kecenderungan, jika dalam organisasi tidak ada yang mampu, mencari pengganti dari luar meskipun harus menyewa serta membayar tinggi. Pemimpin hanya membuat beberapa keputusan penting pada tingkat tertinggi dengan pemahaman yang konseptual. Pemimpin yang efektif dalam organisasi menggunakan desentralisasi dalam membuat keputusannya.

Macam-macam gaya kepemimpinan menurut Suko Susilo, yaitu:

\section{Laissez Faire}

Gaya kepemimpinan laisses faire (bebas lepas) ini memberikan penjelasan bahwa adanya derajat atau intensitas perilaku kepemimpinan yang sangat rendah untuk dua kecenderungan sekaligus. ${ }^{27}$ Pemimpin rendah perhatiannya kepada usaha pembinaan kekompakan kelompok sekaligus memiliki perhatian yang sangat rendah pada penyelesaian tugas-tugas kelompok.

Gaya kepemimpinan ini memberikan kebebasan mutlak kepada para pengikut. Setiap keputusan diserahkan sepenuhnya kepada pengikut.

27 Suko Susilo (2013), Dasar-dasar Psikologi Sosial, Jenggala Pustaka utama, Surabaya, hlm. 168
Pemimpin bersifat pasif dan tidak memberikan contoh kepemimpinan. Pemimpin jenis ini hanya terlibat delam kuantitas yang kecil di mana para bawahannya yang secara aktif menentukan tujuan dan penyelesaian masalah yang dihadapi. Gaya ini sama sekali tidak memberikan perhatian baik pada tugas maupun pada hubungan kerja. Dalam situasi tertentu gaya ini tidak begitu terpuji, karena manajer seperti ini menunjukkan pasif tidak mau ikut campur tangan secara aktif dan pasif. ${ }^{28}$

2. Otoriter

Gaya pemimpin yang memusatkan segala keputusan dan kebijakan yang diambil dari dirinya sendiri secara penuh. Segala pembagian tugas dan tanggung jawab dipegang oleh si pemimpin yang otoriter tersebut, sedangkan para bawahan hanya melaksanakan tugas yang telah diberikan.Pemimpin merupakan pihak yang berkuasa, sedangkan orang lain adalah pihak yang hanya memiliki tugas, kewajiban dan tanggung jawab. Dalam gaya kepemimpinan otoriter, pemimpin adalah segala-galanya. Pengikut dipandang sebagai pihak yang hanya melaksanakan perintah, sehingga pengikut hanya menerima instruksi, dan tidak diperkenankan membantah atau mengeluarkan pendapat. ${ }^{29}$

Kelebihan model kepemimpinan otoriter ini ada di pencapaian prestasinya. Tidak ada satupun tembok yang mampu menghalangi langkah pemimpin ini. Ketika dia memutuskan suatu tujuan, itu adalah harga mati, tidak ada alasan, yang ada adalah hasil. Langkah - langkahnya penuh perhitungan dan sistematis.

Dingin dan sedikit kejam adalah kelemahan pemimpin dengan kepribadian merah ini. Mereka sangat mementingkan tujuan sehingga tidak pernah peduli dengan cara. Makan atau dimakan adalah prinsip hidupnya.Pemimpin ini paham betul dengan apa yang diinginkanya dan

28Miftah Thoha (2011), Perilaku Organisasi Konsep Dasar Dan Aplikasinya, PT Raja Grafindo persada, Jakarta, hlm. 312-314

29 Arini Tathagati (2016), Orang Kreatif Memimpin Dunia, Progressio Jakarta, Hlm. 37 
giat mengejarnya. Gaya kepemimpinan ini memiliki ciri-ciri, antara lain menjadikan organisasi menjadi milik pribadi, menetapkan tujuan pribadi dengan tujuan organisasi, memandang bawahan sebagai alat yang tidak berdaya, tidak mau menerima kritik, saran dan pendapat, bergantung kepada kekuasaan formal yang dimilikinya dan memimpin dengan cara paksa. ${ }^{30}$

\section{Demokratis}

Gaya kepemimpinan demokratis adalah gaya pemimpin yang memberikan wewenang secara luas kepada para bawahan. Setiap ada permasalahan selalu mengikutsertakan bawahan sebagai suatu tim yang utuh. Dalam gaya kepemimpinan demokratis pemimpin memberikan banyak informasi tentang tugas serta tanggung jawab para bawahannya.Kepemimpinan demokratis memiliki kecenderungan perilaku yang sangat memperhatikan hubungan-hubungan personal yang dapat membimbing kekompakan dengan dibarengi perhatian yang tinggi terhadap produktivitas kelompok.Dalam kepemimpinan demokratis, pemimpin memandang pengikut sebagai bagian dari organisasi, sehingga pemimpin memberikan tanggung jawab dan wewenang kepada semua pihak. Pengikut diberi kesempatan untuk menyampaikan masukan dan kritik dalam proses mencapai tujuan. Pemimpin bertanggungjawab untuk mengarahkan, mengontrol, mengevaluasi, dan mengkoordinasikan segala sesuatu dalam klompok. ${ }^{31}$

\section{Kekeluargaan}

Fokus perilaku kepemimpinan ini adalah bahwa anggota kelompok yang dipimpin, dengan segenap harapan dan kebutuhannya sangat diperhatikan serta pemimpin mau dengan senang hati mendengar suara bawahan. ${ }^{32}$

30Jamal Ma'mur Asmani (2012), Tips Menjadi Kepala Sekolah Profesional, Diva Press, Jogjakarta, hlm. 75

${ }^{31}$ Arini Tathagati (2016), Orang Kreatif Memimpin Dunia, Progressio Jakarta, Hlm. 37

${ }^{32}$ Suko Susilo (2013), Dasar-dasar Psikologi Sosial, Jenggala Pustaka utama, Surabaya, hlm. 175
Gaya kepemimpinan kepala sekolah merupakan harapan yang tinggi bagi peningkatan kualitas pendidikan, karena keberhasilan kepemimpinan disekolah akan mempunyai pengaruh secara langsung terhadap hasil belajar siswa. ${ }^{33}$

Konsep seorang pemimpin pendidikan tentang kepemimpinan dan kekuasan yang memproyeksikan diri dalam bentuk sikap, tingkah laku dan sifat. Kegiatan kepemimpinan yang dikembangkan dalam lembaga pendidikan atau unit administrasi pendidikan yang dipimpinnya akan mempengaruhi situasi kerja, mempengaruhi kerja anggota staf, sifat, hubungan-hubungan kemanusian diantara sesama, dan akan mempengaruhi kualitas hasil kerja yang mungkin dapat dicapai oleh lembaga atau unit administrasi pendidikan tersebut.

Adapun Gaya kepemimpinan, pada dasarnya mengandung pengertian sebagai suatu perwujudan tingkah laku dari seorang pemimpin, yang menyangkut kemampuannya dalam memimpin. Perwujudan tersebut biasanya membentuk suatu pola atau bentuk tertentu. Pengertian gaya kepemimpinan yang demikian ini sesuai dengan pendapat yang disampaikan oleh Davis dan Newstrom. Keduanya menyatakan bahwa pola tindakan pemimpin secara keseluruhan seperti yang dipersepsikan atau diacu oleh bawahan tersebut dikenal sebagai gaya kepemimpinan. ${ }^{34}$

Setidaknya pola dalam gaya kepemimpinan terbagi kedalam empat gaya; diantaranya, pertama, gaya kepemimpinan yang berpola sangat tidak memperhatikan hasil produksi dan juga tidak memperhatikan kekompakan anggotanya, kedua, gaya kepemimpinan yang memiliki pola sangat memperhatikan hasil produksi tatapi rendah sekali perhatiannya pada

33 E. Mulyasa (2011), Maajemen dan Kepemimpinan Kepala sekolah, Bumi Aksara, Jakarta, hlm. 183

34 Keith Davis, and John W. Newstrom (2010), Human Behaviour at Work : Organizational Behaviour. New York Mc. Graw-Hill Inc, halm. 267 
kekompakan antar anggota, ketiga, gaya kepemimpinan yang berpola sangat memperhatikan kekompakan anggota tetapi rendah perhatiannya pada hasil produksi, dan keempat, gaya kepemimpinan yang memiliki pola sangat memperhatikan hasil produksi sekaligus juga sangat memperhatikan kekompakan anggota. ${ }^{35}$

\section{Kajian tentang Kepala Madrasah}

Berdasarkan beberapa kajian konsep kepala madrasah dapat dijelaskan bahwa seorang guru yang mempunyai kemampuan untuk memimpin segala sumber daya yang ada pada suatu madrasah sehingga dapat didayagunakan secara maksimal untuk mencapai tujuan bersama. Sebagaimana telah kita ketahui, kepala madrasah sebagai pemimpin pendidikan ditingkat operasional memiliki posisi sentral dalam membawa keberhasilan lembaga pendidikan. Kepala madrasah berperan memandu, menuntun, membimbing, memberi dan membangunkan motivasi kerja, mengemudikan organisasi, menjalin jaringan komunikasi yang baik, memberi supervisi/pengawasan yang efisien dengan ketentuan waktu dan perencanaan.

Jadi,Kepemimpinan Kepala Madrasah yaitu proses yang dilakukan oleh kepala madrasah untuk mempengaruhi, mengkoordinir, dan menggerakkan orang lain yang ada hubungan dengan pengembangan ilmu pendidikan dan pelaksana pendidikan dan pembelajaran agar kegiatan-kegiatan yang dijalankan dapat lebih efesien dan efektif demi tercapainya tujuan-tujuan pendidikan pembelajaran.

\section{Pengaruh Gaya Kepemimpinan Kepala Madrasah Terhadap Motivasi Belajar Siswa}

Seseorang melakukan aktivitas karena di dorong oleh adanya faktor-

35 Zaenal Arifin. (2016). Efektifitas Kepemimpinan Lembaga Pendidikan Islam di Pesantren. Jurnal Pemikiran Keislaman, 27(1), 40 64. https://doi.org/10.33367/tribakti.v27i1.258 faktor, kebutuhan biologis, instink, dan unsur-unsur kejiwan lainnya serta adanya pengaruh perkembangan budaya manusia. Dalam persoalan ini Skinner lebih cenderung merumuskan dalam bentuk mekanisme stimulus dan respon. Stimulus dan respon inilah memunculkan suatu aktivitas. ${ }^{36}$ _Dalam hubungan dengan belajar, yang penting adalah bagaiman menciptakan kondisi atau proses yang mengarahkan siswa melakukan aktivitas belajar. Peran kepala sekolah juga berpengaruh dalam meningkatkan motivasi belajar siswa.

Siswa adalah salah satu komponen manusiawi yang menempati posisi sentral dalam proses belajar mengajar. Di dalam proses tersebut siswa sebagai pihak yang ingin meraih cita-cita memiliki tujuan dan ingin mencapainya secara optimal. Siswa menjadi faktor penentu sehingga menuntut dan dapat mempengaruhi segala sesuatu yang diperlukaan untuk mencapai tujuan belajarnya. ${ }^{37}$

Untuk dapat mencapai tujuan dalm proses belajar, siswa di tuntut untuk mengembangkan dan membangkitkan motivasi yang ada di dalam dirinya secara terus menerus. Untuk dapat membangkitkan dan mengembangkan motivasi dalam belajar, siswa daapt melakukannya denagn menentukan atau mengetahui tujuan belajar yang hendak di capai, menanggapi dengan positif pujian atau dorongan dari orang lain menentukan target ataau sasaran penyelesaian tugas belajar dan lain-lain. ${ }^{38}$

Motivasi berkaitan erat dengan tujuan, dan tujuan berkaitan erat dengan kebutuhan. Seseorang akan terdorng melaukan sesuatu bila merasa ada suatu kebutuhan. Kebutuhan timbul karena adanya keadaan yang tidak seimbang, tidak serasi atau rasa ketegangan yang menuntut suatu kepuasan. Keadaan yang tidak seimbang atau adanya rasa tidak puas,

36 Sardiman AM, 2011,Interaksi dan Motivasi Belajar Mengajar, Jakarta: RajaGrafindo Persada, Hal. 75

37 Ibid,... Halm. 109

38 Dimyati dan Mudjiono, Op.Cit, Halm. 
perlukan motivasi yang tepat. Kalau kebutuhan tidak terpenuhi, amaka aktivitas itu akan berkurang dan sesuai dengan dinamika kehidupan manusia, mak akan timbul tuntutan kebutuhan yang baru. Hal ini menunjukkan bahwa kebutuhan manusia bersifat dinamis, berubah-ubah sesuai dengan sifat kehidupan manusia itu sendiri. ${ }^{39}$

\section{Metode Penelitian}

Penelitian ini menggunakan pendekatan kualitatif, sementara penggalian datanya diimput dengan metode obervasi, interview, dan dokumentasi. Sedangkan analisis datanya menggunakan analisis kualitatif dengan tiga tahapan, yakni 1) Reduksi data berlangsung terus menerus selama penelitian berlangsung bahkan sebelum data benar-benar terkumpul sudah mengantisipasi akan adanya reduksi data sudah tampak sewaktu memutuskan kerangka konseptual, wilayah penelitian, permasalahan penelitian, dan penentuan metode pengumpulan data. Selama pengumpulan data berlangsung sudah terjadi tahapan reduksi, selanjutnya (membuat ringkasan, mengkode, menelusuri tema, membuat gugus-gugus, menulis memo). Proses ini berlanjut sampai pasca pengumpulan data di lapangan, bahkan pada akhir pembuatan laporan sehingga tersusun lengkap. Sementara penyajian data atau display data dimaksudkan untuk menemukan pola-pola yang bermakna serta memberikan kemungkinan adanya penarikan kesimpulan dan pengambilan tindakan. Penyajian data dalam penelitian ini juga dimaksudkan untuk menemukan suatu makna dari data-data yang telah diperoleh, kemudian disusun secara sistematis, dari bentuk informasi yang kompleks menjadi sederhana namun selektif.

Yang terakhir kegiatan analisis pada tahap ketiga adalah menarik kesimpulan dan verifikasi. Sejak pengumpulan data peneliti berusaha mencari makna atau arti dari simbol- simbol, mencatat, keteraturan pola, penjelasan-penjelasan, dan alur sebab akibat yang terjadi. Dari kegiatan ini dibuat simpulan-simpulan yang sifatnya masih terbuka, umum, kemudian menuju ke yang spesifik/rinci. Kesimpulan final diharapkan dapat diperoleh setelah pengumpulan data selesai

\section{Hasil Penelitian \\ Gaya kepemimpinan Kepala Madrasah Tsanawiyah Al-Huda Desa Mojoduwur Kecamatan Ngetos Kabupaten Nganjuk.}

Kepemimpinan

sangat

mempengaruhi dan menentukan tujuan organisasi, memotivasi perilaku pengikut untuk mencapai tujuan, dan mempengaruhi untuk memperbaiki kelompok. Menurut Laila uswatun hasanah, S. PdI mengatakan bahwa:

"Kepemimpinan di bidang pendidikan memiliki pengertian bahwa pemimpin harus memiliki keterampilan dalam mempengaruhi, mendorong, membimbing, mengarahkan dan menggerakkan orang lain yang ada hubungannya dengan pelaksanaan dan pengembangan pendidikan dan pengajaran ataupun pelatihan agar segenap kegiatan dapat berjalan secara efektif dan efisien yang pada gilirannya akan mencapai tujuan pendidikan dan pengajaran yang telah ditetapkan. ${ }^{40}$

Sedangkan gaya kepemimpinan dalam pendidikan juga dapat mempengaruhi, menggerakkan, dan mengkoordinasikan personal di lingkungan pendidikan pada situasi tertentu agar mereka melalui kerja sama mau bekerja dengan penuh tanggung jawab dan ikhlas demi tercapainya tujuan pendidikan yang telah dirumuskan. K. Samsudin mengatakan bahwa:

Gaya kepemimpinan dalam Islam adalah perilaku pemimpin yang interaktif yang mampu mempengaruhi individuindividu untuk melaksanakan tugasnya dalam rangka memberikan arahan, petunjuk yang lebih baik dalam mencapai

${ }^{40}$ Hasil wawan cara dengan operator MTs Al huda, tanggal 11 Juli 2017 
tujuan yang telah ditetapkan, mengembangkan, memegang teguh, dan menjaga kepercayaan yang dipercayakan kepadanya. Begitu juga dengan peran kepala madrasah sebagai pemimpin harus mampu untuk meningkatkan peran strategis dan teknis dalam meningkatkan kualitas lembaga yang dipimpinnya. Hal lain yang perlu diperhatikan juga adalah gaya kepemimpinan kepala madrasah sebagai agen perubahan dalam meningkatkan kualitas keagamaan sangat penting. Karena dengan dasar agama seluruh warga/komunitas madrasah dapat menjalankan aktifitas pembelajaran dan pergaulan di lingkungan masyarakat dengan didasari oleh nilai-nilai keislaman.

Tidak semua kepala madrasah memiliki gaya kepemimpinan yang cocok dan sesuai dalam mengelola dan memimpin guru, staf, dan siswa pada sebuah madrasah yang boleh dikatakan bertempat di daerah terpencil, yaitu madrasah tsanawiyah Al-Huda Ngetos Nganjuk. Kepala madrasah bisa dikatakan sebagai pemimpin formal atas jabatannya sebagai kepala madrasah dan juga dapat dikatakan sebagai pemimpin agama karena kelebihan dan kemampuannya dalam bidang agama. Beliau disamping berprofesi sebagai guru juga berprofesi sebagai ustadz, beliau juga seorang qori', di kecamatan Nganjuk. Gaya kepemimpinan yang di terapkannya merupakan usaha kepala madrasah tersebut agar tercapainnya visi, misi dan tujuan dari madrasah tsanawiyah Al-Huda Ngetos Nganjuk.

Apabila dikaitkan dengan kepemimpinan dalam Islam, khususnya perkara figur yang mempengaruhi dalam proses, jelas tidak dapat dilepaskan dari kepemimpinan Muhammad Rasulullah SAW sebagai tokoh sentral yang wajib dijadikan tolak ukur dan teladan yang akurat dalam menentukan bentuk nilai atau karakteristik kepemimpinan dalam Islam.

Seorang pemimpin merupakan panutan dari yang dipimpinnya. Majumundurnya sesuatu kelompok masyarakat banyak, tergantung pada etika pemimpinnya. Seorang pemimpin harus beretika mulia. Etika pemimpin yang baik mempunyai karakter sebagai berikut: Shiddiq (jujur), amanah (terpercaya), tabligh (menyampaikan), fathanah (cerdas).

Dalam khasanah kepemimpinan modern, seorang leader tidak hanya dituntut untuk memiliki kharisma tetapi juga dituntut untuk cerdik memahami lingkungannya. Ini disebut sebagai "suatu kesadaran dan kemampuan untuk selalu dapat beradaptasi dengan lingkungan sosial dan juga tuntutan anggota. Seperti halnya kepemimpinan yang dijalankan oleh Rasulullah.

Kepala madrasah sebagai orang yang dituakan di madrasah harus selalu memberikan bimbingan dan pengarahan kepada bawahannya, baik yang berhubungan dengan bimbingan mental, bimbingan dalam bidang moral, bimbingan dan pembinaan di bidang fisik, dan bimbingan dan pembinaan dalam bidang artistik.

Seorang kepala madrasah yang demokratis mempunyai pandangan bahwa dirinya merupakan bagian dari kelompok, ia pasti memilki sifat terbuka kepada siapapun, ia pasti mau mendengar saran dan masukan dari siapapun, dan juga pasti mau berinteraksi kepada siapapun. Ia menyadari kalau keputusan yang diambil secara musyawaroh akan lebih meringankan tugas- tugasnya dan para anggotanyapun pasti akan lebih merasa bahwa dirinya ikut bertanggung jawab atas keputusan yang diambilnya.

Seorang kepala madrasah yang baik yaitu harus mau menerima masukan masukan dari orang lain, dan juga harus bisa mengambil keputusan secara bijak, tanpa harus menyakiti atau menyinggung orang lain. Di dalam rapat seorang pemimpin harus bisa menciptakan komunikasi yang sehat, jangan memonopoli pembicaraan sendiri, harus banyak memberi kesempatan orang lain untuk berbicara, dan seorang pemimpin harus menghargai pendapat orang lain serta harus bisa memandu jalannya rapat (fokus pembicaraan) dengan bijak agar 
tidak sampai arah pembicaraan yang melebar kemana-mana. Dengan sikap demokratis seorang pemimpin akan mampu membangkitkat rasa sifat kebersamaan antar personal di suatu lembaga , dan rasa keberanian bagi bawahan untuk memberikan saran-saran dan masukan kepada pemimpin. Namun sekali tempo seorang pemimpin juga harus menggunakan gaya kepemimpinan otoriternya dalam batas-batas yang wajar, yaitu dalam situasi dan kondisi tertentu yang mengharuskan bapak kepala madrasah bersifat otoriter misalnya ketika melaksanakan program tertentu, padahal ada 2 atau 3 orang guru yang tidak sependapat dengan program tersebut, meskipun pada akhirnya mereka setuju dan melaksanakan program unggulan madrasah tersebut. Tetapi dengan kekuasaannya kepala madrasah memutuskan untuk memasukan program tersebut.

\section{Strategi yang Digunakan Kepala Madrasah dalam Pelaksanaan Gaya kepemimpinan Kepala Madrasah Tsanawiyah Al-Huda Desa Mojoduwur Kecamatan Ngetos Kabupaten Nganjuk.}

Strategi kepala madrasah dalam kepemimpinannya menggunakan 3 langkah dalam kerjanya yakni perencanaan, kemitraan dan evaluasi program.

\section{Perencanaan}

Perencanaan adalah unsur penting dan strategis yang memberikan arah dalam pelaksanaan kegiatan untuk mencapai tujuan atau sasaran yang dikehendaki. Dalam bidang pendidikan, perencanaan merupakan salah satu faktor kunci efektifitas pelaksanaan kegiatan-kegiatan pendidikan untuk mencapai tujuan pendidikan yang diharapkan bagi setiap jenjang dan jenis pendidikan pada tingkat lokal maupun nasional.

Dalam dunia manajemen pendidikan, fungsi pertama kepala sebagai seorang manager adalah membuat perencanaan yang baik untuk programprogram pendidikan di madrasah. Sebagai planner kepala madrasah dituntut untuk kreatif dan inovatif dalam memunculkan ide-ide konstruktif guna meningkatkan mutu pendidikan.

Perencanaan program-program madrasah tidak harus murni inisiatif kepala madrasah, tetapi dapat juga berasal dari masukan siswa, para guru atau karyawan. Namum kepala dituntut untuk mensistematisasikan usulan-usulan yang mengemuka dan merekayasa kegiatankegiatan yang dapat dilakukan untuk mewujudkan ide-ide tersebut. Untuk membantu hal ini, kepala madrasah dapat memusyawarahkan ide, gagasan, dan program-program yang akan direalisasikan dalam rapat-rapat atau pertemuanpertemuan dalam segenap warga madrasah.

2. Kemitraan (andil)

Strategi yang dapat dilakukan oleh para pemimpin lembaga pendidikan untuk melaksanakan semua kegiatannya adalah dengan memberikan motivasi dan dorongan kepada segenap warga madrasah. Di samping dukungan secara moril yang lebih bersifat verbal, kepala madrasah juga memberikan dukungan kepada warga madrasah dengan tindakan nyata yang berupa keikutsertaannya dalam melaksanakan kegiatan-kegiatan yang dilaksanakan di madrasah.

Terkait dengan ini, kepala madrasah tsanawiyah Al-Huda Ngetos Nganjuk telah berupaya untuk bermitra dan turut andil mendukung serta terlibat secara langsung dalam kegiatan yang dilaksanakan di madrasah. Keikutsertaan kepala madrasah secara langsung dimaksudkan agar kegiatan itu berjalan maksimal dan menjadikan motivasi tersendiri bagi pelaksana kegiatan.

3. Evaluasi terhadap program yang dijalankan

Evaluasi dalam suatu organisasi memiliki peranan yang sangat penting dalam strategi untuk mengetahui berbagai hal yang berkaitan dengan perkembangan, kemajuan, kemunduran suatu organisasi, guna ditindaklanjuti sebagai langkahlangkah improvisasi organisasi menuju kearah yang lebih baik dan maju. 
Dalam teori manajemen, evaluasi menjadi unsur penting keberhasilan sebuah manajemen. Sebuah perencanaan yang baik dan telah dilanjutkan dengan pengorganisasian yang baik tidak cukup untuk dijadikan sebuah aktivitas berlangsung sesuai dengan target yang diinginkan. Untuk itu, diperlukan evaluasi yang berkelanjutan dan menyeluruh. Dengan evaluasi tersebut, pimpinan dan bawahan dapat mengetahui target-target yang telah tercapai dan yang belum terlaksana dengan baik. Di samping itu, apersepsi dan evaluasi diharapkan dapat menjadi motivasi pimpinan dan bawahan untuk memperbaiki dikesempatankesempatan lainnya.

Evaluasi adalah usaha mengambil suatu keputusan terhadap sesuatu dengan ukuran baik buruk, dan penilaian bersifat kualitatif. Mengadakan penilaian meliputi dua langkah tersebut, yaitu mengukur dan menilai. Adapun unsur-unsur pokok dalam suatu evaluasi yaitu: adanya obyek yang akan dievaluasi, tujuan pelaksanaan evaluasi, alat pengukuran (standar pengukuran/perbandingan), hasil evaluasi apakah bersifat kualitatif maupun kuantitatif.

Di madrasah tsanawiyah Al-Huda Evaluasi tersebut dilaksanakan dalam rapat dan secara kondisional bersama para guru. Pengawasan atau evaluasi yang dilakukan kepala madrasah berguna untuk mengetahui realisasi kegiatan warga madrasah dan apakah pencapaian tujuan sesuai yang diinginkan, selanjutnya apakah perlu diadakan suatu perbaikan. Oleh karena itu, kegiatan evaluasi dimaksudkan untuk mencegah penyimpangan dalam pelaksanaan pekerjaan, menilai proses dan hasil kegiatan sekaligus melakukan tindakan perbaikan.

\section{Interaksi Sosial kepala Madrasah dengan Seluruh Warga Madrasah Tsanawiyah Al-Huda Desa Mojoduwur Kecamatan Ngetos Kabupaten Nganjuk.}

Manusia adalah makhluk individu yang tidak dapat dipisahkan antara jiwa dan raganya. Sedangkang sebagai makhluk sosial seorang individu tidak dapat beerdiri sendiri, saling membutuhkan antara yang satu dengan yang lainnya, dan saling mengadakan hubungan sosial ditengah tengah masyarakat. Hubungan sosial/interaksi sosial adalah suatu kegiatan yang dilakukan secara terencana untuk menghubungkan kepentingan antarindividu, individu denagan kelompok atau antarkelompok baik secara langsung dan tidak langsung dengan tujuan untuk menciptakan rasa saling pengertian dan kerjasama yang menguntungkan. Bapak Agung Santoso berpendapat bahwa:

Proses interaksi sosial dapat berlangsung secara langsung dengan tatap muka maupun secara tidak langsung atau menggunakan media seperti: telephon, televisi, surat menyurat dan lain-lain. Interaksi sosial yang terjadi antara dua individu yang bertemu secara langsung dapat berupa saling bertegur sapa, berjabat tangan, dan berbicara. Hal ini sesuai budaya di madrasah Tsanawiyah Al-Huda Ngetos Pembiasaan Senyum dan Salam

Sangat dianjurkan setiap pemeluknya untuk memberikan sapaan pada orang lain dengan mengucapkan salam. Ucapan salam disamping sebagai sapaan dan doa bagi orang lain juga sebagai bentuk persaudaraan antar sesama manusia. Secara sosiologi sapaan dan salam dapat meningkatkan interaksi antar sesama, dan berdampak pada rasa penghormatan sehingga antara sesama saling dihargai dan dihormati.

\section{Kesimpulan}

Berdasarkan hasil penelitian melalui pengamatan, wawancara, paparan data, analisis, dan dokumentasi yang telah diuraikan di bab IV dapat disimpulkan sebagai berikut: pertma, Gaya kepemimpinan yang diterapkan oleh kepala madrasah tsanawiyah Al-Huda adalah Demokrasi. Kepala madrasah orangnya sangat demokratis, beliau menyadari bahwa dirinya merupakan bagian dari kelompok, memiliki sifat terbuka, dan memberi kesempatan kepada para tenaga kependidikan untuk ikut berperan aktif dalam membuat perencanaan, keputusan serta menilai 
kinerjanya. Dalam rapat sekolah kepala madrasah melibatkan dirinya secara langsung dan membuka interaksi dengan tenaga kependidikan. Keputusan yang diambil kepala madrasah dilakukan berdasarkan musyawarah. Kepala sekolah selalu memberi kesempatan kepada para tenaga pendidik untuk memberikan masukan dan hasil keputusan berada di tangan kepala madrasah sesuai musyawarah.

Kedua, Strategi yang dilakukan kepala madrasah dalam melaksanakan kepemimpinannya adalah:

a. perencanaan (niat)

Sebelum melakukan kegiatan maka sikap mental yang harus dibangun pada masing-masing individu adalah niat karena niat merupakan awal untuk melakukan semua pekerjaan demi untuk meraih ridha dari Allah. Dengan sikap mental yang demikian maka kegiatan akan berjalan dan sesuai dengan hakikat sesungguhnya, yaitu : sikap mental yang diproses imajinasi dan pandangan ke depan yang terarah berdasarkan penilaian yang benar. Sehingga dengan demikian perencanaan yang dibuat dapat diharapkan mencapai hasil maksimal dan dilandasi dengan niat untuk kemaslahatan serta berisikan berbagai kegiatan yang berorientasi pelaksanaan.

b. bermitra serta andil

Kepala madrasah menjalankan program kemitraan dalam melaksanakan gaya kepemimpinannya, mendukung dan ikut serta dalam kegiatan yang dilaksanakan di madrasah. Hal ini bertujuan dengan adanya kemitraan kepala madrasah secara langsung menjadikan guru, karyawan dan siswa semangat melaksanakan kegiatan-kegiatan keagamaan yang ada di madrasah.

c. evaluasi

Di madrasah tsanawiyah al-huda Ngetos Nganjuk Dalam setiap kegiatan dan program kerja selalu mengadakan evaluasi untuk mengetahui keberhasilan dari program yang telah dijalankan dan dilaksanakan dan juga untuk membenahi setiap kekurangan yang telah terjadi agar tidak terulang di kegiatan yang akan datang. Evaluasi tersebut dilaksanakan ketika musyawarah dan pelaksanaan rapat bersama semua dewan guru, baik pada rapat tiga bulanan maupun satu bulanan. Evaluasi juga dilaksanakan pada rapat yang tidak terjadwal yaitu rapat kondisional.

Ketiga, Kepala madrasah tsanawiyah Al-Huda Ngetos Nganjuk menjalin interaksi sosial secara horizontal dengan guru dan karyawan madrasah tsanawiyah Al-Huda Ngetos Nganjuk dan menjalin interaksi sosial secara vertikal dengan siswa siswi madrasah tsanawiyah Al-Huda Ngetos Nganjuk.

Interaksi sosial secara horizontal yaitu interaksi sosial antara individu atau kelompok yang sederajat yang saling berkepentingan atau memiliki kepentingan yang sama. sedangkan interaksi sosial secara vertikal yaitu interaksi sosial yang didasarkan pada perbedaan kedudukan. 


\section{Daftar Pustaka}

Arifin, Zaenal. (2016). Efektifitas Kepemimpinan Lembaga Pendidikan Islam di Pesantren. Jurnal Pemikiran Keislaman, 27(1), $\quad 40 \sim 64$. https://doi.org/10.33367/tribakti.v2 $\underline{7 i 1.258}$

Asmani, J.M. (2012) Tips Menjadi Kepala Sekolah Profesional. Bandung: Diva Press,

Burhanuddin, 2013. Analisis Administrasi Manajemen dan Kepemimpinan Pendidikan, Jakarta: Bumi Aksara,.

Danim, S. (2010), Visi Baru Manajemen Sekolah,PT Bumi Aksara, Jakarta.

Dwiyanto, A. (2010) Reformasi Birokrasi, kepemimpinan dan Pelayanan Publik. Yogyakarta: Gava Media.

Emzir. (2012) Metodologi Penelitian Kualitatif Analisis Data. Raja Grafindo Persada, Jakarta.

Ghozali, et.al. 2011. Administrasi Sekolah, Cahaya Budi, Jakarta.

Gunawan, I. (2015) Metode Penelitian Kualitatif Teori Dan Praktik. Bumi Aksara,Jakarta.

Hendiyat Soetopo dan Wasty Suemanto (2011), Kepemimpinan dan Supervisi Pendidikan, Bina Aksara, Bandung.

Hidayah, N. (2016) Kepemimpinan Visioner Kepala Sekolah DalamMeningkatkan Mutu Pendidikan. Ar-Ruzz Media, Yogyakarta.

Kaloh, J. (2010) Kepemimpinan Kepala Daerah. Sinar Grafika, jakarta.

Mardalis. (2014) Metode Penelitian Suatu Pendekatan Proposal. Bumi Aksara,Jakarta.

Muhaimin (2010) Manajemen dan Kepemimpinan Sekolah/Madrasah.
Kencana Prenada Media Group, Jakarta.

Mulyadi (2010) Kepemimpinan Kepala Madrasah dalam Mengembangkan Budaya Mutu. UIN Maliki Press, Malang.

Mulyasa, H.E. (2011) Menjadi Kepala Sekolah Profesional. Remaja Rosdakarya, Bandung.

Mulyasa, H.E. (2012) Manajemen Dan Kepemimpinan Kepala Sekolah. Bumi Aksara, Jakarta.

Nawawi, H. 2011. Administrasi Pandidikan, CV Haji Masagung, Jakarta.

Noor, I.(2011) Manajemen Kepemimpinan Muhammad SAW: Mencontoh Teladan Kepemimpinan Rasul untuk Kesempurnaan Manajemen Modern. Mizan, Bandung.

Putra, N. (2013) Metode Penelitian Kualitatif Manajemen, Raja Grafindo Persada, Jakarta.

Qomar,M. (2012), Manajemen Pendidikan Islam, Erlangga, Malang.

Raihani (2010) Kepemimpinan Sekolah Transformatif. LkiS, Yogyakarta.

Sardiman AM. 2011. Interaksi dan Motivasi Belajar Mengajar, RajaGrafindo Persada, Jakarta.

Shulhan, M. (2010), Administrasi Pendidikan, PT Bina Ilmu, Jakarta.

Soim (2011), Profes ikeguruan, Lembaga Studi Cinta Ilmu (eLScI), Jakarta.

Sondang, S. 2011. Teori dan Praktek Kepemimpinan, Renika Cipta, Jakarta.

Suprayogo, I. (2011) Menuju Indonesia Baru. UIN Maliki Press, Malang. 
Susilo, S. (2013) Dasar-Dasar Psikologi Sosial. Jenggala Pustaka Utama.Tathagati, A.(2016) Orang Kreatif Memimpin Dunia. , Jakarta: Progressio.

Sutisna, O. (2011), Administrasi Pendidikan, Bandung: Angkasa.

Wahid, S. (2011). Berguru Pada Realitas. , Malang: UIN Maliki Press.

Wahjosumidjo. (2010). Kepemimpinan Kepala Madrasah Tinjauan Teoritik dan Permasalahannya. Jakarta: PT Raja Grafindo Parsada. 